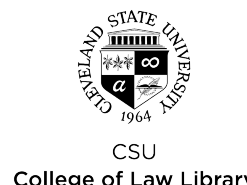

Cleveland State University

College of Law Library

\title{
EngagedScholarship@CSU
}

2002

\section{Stem Cells, Cloning, and Abortion: Making Careful Distinctions}

Dena S. Davis

Cleveland State University, d.davis@csuohio.edu

Follow this and additional works at: https://engagedscholarship.csuohio.edu/fac_articles

Part of the Bioethics and Medical Ethics Commons, and the Other Law Commons

How does access to this work benefit you? Let us know!

\section{Original Citation}

Dena S. Davis, Stem Cells, Cloning, and Abortion: Making Careful Distinctions, 2 American Journal of Bioethics 47 (February 2002)

This Article is brought to you for free and open access by the Faculty Scholarship at EngagedScholarship@CSU. It has been accepted for inclusion in Law Faculty Articles and Essays by an authorized administrator of EngagedScholarship@CSU. For more information, please contact research.services@law.csuohio.edu. 
Zoloth tells a fascinating tale of bioethicists seduced by science-and resisting that seduction. She commends to our thought a number of interesting problems: Might just-war theory speak to the problem of new stem cell technologies? How shall we frame the consent process in this new scientific world? How should we structure the role of bioethicist as "expert consultant" and shelter consultants from conflicts of interest? But the deeper challenge of her article is in her call for "Exodic thinking." The revolution in medicine, she seems to imply, requires another kind of revolution, one that involves "foregrounding justice." She sees our decisions about these new technologies as, literally, revolutionary opportunities: opportunities for the reconstitution of America, the refoundation of the City on the Hill. She invokes examples-the moment before the entry of the Hebrews into the promised land and a Puritan moment of constitution-commonly associated with political revolution (see Walzer 1976; 1985; and Hill 1997); and speaks, in biblical words used by many revolutionaries, of "upending the world" (see Hill 1975).

But she also notes that stem cell research manages to gather together in "the same room" all of the bioethical problems that have most vexed and divided us: sex, IVF, abortion, germ-line intervention. We must beware of attempting to found our new city on the basis of moral decisions about matters that divide us. Constitutions establish our identity as a community; they should be based upon what we hold in common. A constitution that takes a posi- tion-even a compromise position-on a moral issue that divides its citizens, calls out for its own destruction (Americans know this by experience). So perhaps the occasion of our confrontation by a morass of ethical issues on which we do not agree is not the proper occasion for a radical re-vision of our community. Perhaps we must simply muddle through as we are already constituted-a people who, after all, already believe in justice; a people who are not poised to enter a new land, but who are bent upon improving the one we have.

\section{References}

Arendt, H. 1968. Between past and future. New York: Penguin Books.

Green, R. M. 2002. Determining moral status. The American Journal of Bioethics 2(1): 20-30.

Hill, C. 1975. The world turned upside down. Harmondsworth: Penguin Books.

\section{Puritanism and revolution. London: St. Martins}

Press.

Maienschein, J. 2002. What's in a name: Embryos, clones, and stem cells. The American Journal of Bioethics 2(1): 12-19.

Walzer, M. 1976. The revolution of the saints. Cambridge, MA: Harvard University Press.

\section{Exodus and revolution. New York: Basic Books.}

Zoloth, L. 2002. Jordan's banks: A view from the first years of human embryonic stem cell research. The American Journal of Bioethics 2(1): 3-11.

\section{Stem Cells, Cloning, and Abortion: Making Careful Distinctions}

Dena S. Davis, Cleveland-Marshall College of Law

The current controversy over federal funding for research involving stem cells derived from very early embryos is situated between two other equally difficult issues: abortion and cloning. As Laurie Zoloth (2002) says, talk about stem cells is "directly proximate" to the abortion debate. Nonetheless, a settled position in favor of abortion rights does not necessarily lead to support for research that involves the death of embryos. Nor should opposition to reproductive cloning necessarily entail opposition to therapeutic cloning. There are important ways in which our attitudes toward research with embryonic stem cells ought to be entwined with our thinking about abortion and cloning, but there are also some very important distinctions which are getting lost in the noisy debate.

With regard to abortion, it is important to remember that the embryos from which stem cells are derived have never been and will never be within a woman's body. I have noticed recently that a lot of acquaintances, when we are talking about stem cells, say, "Well, of course I'm prochoice," as if that settles the question of how they feel about stem cell research. But think about the most common reasons people give for being pro-choice: women have the right to decide what to do with their bodies; women can compete effectively in the workplace only if they can reliably control their fertility; only the individual woman can decide if she wants to be a parent; making abortion illegal risks women's lives; unwanted children are less likely to fare well. All of these arguments are compatible with the belief that an embryo has some moral status, even quite weighty moral status, just not weighty enough to 
overbalance the woman's right to make that choice. Judith Jarvis Thompson (1971), in a famous and influential article, has shown that even imagining the embryo as having the same moral status as an adult human being, does not entail that a woman is required to function as that person's life support system for nine months. Thus, legally at least, Ronald Green (2002) is not correct when he says that if an embryo were regarded as a woman's moral equivalent from the point of fertilization, a woman's interests could be overridden if they clashed with the moral claims of the embryo or fetus. Laurence Tribe (1990) reminds us that

There is ... only one place in the law where a really significant and intimate sacrifice has been required of anyone in order to save another: the law of abortion. If you woke up with \{Thomson's\} hypothetical violinist attached to you, the law - and, probably, the views of morality held by most people-would permit you to free yourself of him. When the law prohibits a woman from freeing herself of the fetus that is inside her, the law appears to work a harsh discrimination against women even if fetuses count as persons. (1990, 131 \{emphasis in original\})

Thus, even a woman who would never have an abortion herself can be pro-choice, supporting each woman's right to make that decision for herself. Tribe joins legal scholar Guido Calabresi in making the intriguing suggestion that the Supreme Court, when deciding Roe v. Wade, unnecessarily insulted people for whom fetal personhood is a bedrock of their faith. The Court could have said, "Even if the fetus is a person, the Constitution forbids compelling a woman to carry it for nine months and become a mother" (Tribe 1990, 135 \{emphasis in the original\}).

But when the embryo is outside the woman's body, frozen in a pipette somewhere, none of these arguments apply. A person could be firmly pro-choice, out of concern for women's liberty and well-being, and still oppose the destruction of extracorporeal embryos. At the same time, as we have seen in Congress, even some staunch pro-lifers have come out in favor of stem cell research, finding that the prospective benefits for people now struggling with diseases such as diabetes and multiple sclerosis, to name just a few, outweigh the moral claims of very early, unimplanted embryos that would, in most scenarios, be discarded. Thus, thinking clearly and well about stem cell research requires us to give up slogans and knee-jerk reactions.

On the other end of the spectrum, stem cell research calls up the specter of cloning, with all the visceral reactions that word engenders. It is true that Advanced Cell Technology, a Massachusetts biotech company, is trying to use "therapeutic cloning" to derive stem cells. The process, if perfected, would go something like this: Jane needs a new liver, but cadaveric livers are scarce and never perfectly matched. So, a scientist takes cells from Jane's cheek and inserts the DNA into a donor egg that has had the DNA sucked out of it. The egg is coaxed to divide and grow, and, when it is perhaps 32-cells old, it is destroyed. Stem cells are taken from it and are used to grow a new liver that will, of course, have Jane's genetic blueprint and which Jane's body will not reject. The basic technique, somatic cell nuclear transfer, is the same as the process used to create Dolly.

What are the reasons people commonly give for being opposed to cloning of humans? Some objections are based on ignorance, such as the notion that cloning will enable us to "copy" 100 Hitlers or Mother Teresas, full-blown adults with the personalities and characters of their models. (This is the false image of cloning depicted in popular films such as The Sixth Day.) However, as Leon Kass (1997) reminds us, "cloning is not Xeroxing" (19). Here are some other, more thoughtful reasons: concern for children brought up in the "shadow" of the parent, dead sibling, or beloved relative from whom they were cloned; suspicion that parents who choose cloning will do so from narcissistic motives; fear that cloning children "to order" will result in thinking of children more as commodities and less as precious gifts. Kass again: "Through cloning, we can work our wants and wills on the very identity of our children, exercising control as never before" (18). Finally, the huge number of miscarriages and malformed births necessary to produce one Dolly should tell us that we are a very long way from safely using cloning to reproduce human beings (Soules 2001).

But when the issue at stake is therapeutic (rather than reproductive) cloning, none of these reasons applies. The embryos created through this process will be destroyed within the first few days of their creation in order to retrieve their stem cells to begin the process of producing a new organ. People who believe that the embryo from the moment of conception is fully protectable human life will probably find it consistent to oppose therapeutic cloning. Although these embryos are not conceived in the usual way, they do carry the full component of potential "humanhood." But for everyone else, it is difficult to see the objections to therapeutic cloning. Certainly the fears and concerns raised by reproductive cloning cannot reasonably be used to oppose therapeutic cloning.

Ralph Potter, a scholar of ethics, once proposed a system of thinking about ethics in which various "boxes" enclosed important questions. One of the questions was: What do you fear? The fears (legitimate and otherwise) that prompt people to oppose abortion and reproductive cloning are not necessarily relevant to stem cell research.

\section{References}

Green, R. M. 2002. Determining moral status. The American Journal of Bioethics 2(1): 20-30. 
Kass, L. 1997. The wisdom of repugnance. The New Republic, 2 June, 17-26.

Soules, M. 2001. Human reproductive cloning: Not ready for prime time. Fertility and Sterility 76:232-234.

Thomson, J. J. 1971. A defense of abortion. Journal of Philosphy and Public Affairs 1:44-76.
Tribe, L. 1990. Abortion: The clash of absolutes. New York: W. W. Norton \& Company.

Zoloth, L. 2002. Jordan's banks: A view from the first years of human embryonic stem cell research. The American Journal of Bioethics 2(1): 3-11.

\section{Can Moral Worthiness Be Seen Using a Microscope?}

David Steinberg, Lahey Clinic Medical Center

Ronald Green (2002) asks "how we establish the moral status of an entity or, what is the same, the degree of moral protection it should receive." Starting with the chemical attraction of sperm to egg, he treats us to a superbly told biology lesson on fertilization and embryonic development. The facts, he tells us, document a "complex and extended process" rather than "definitive marker events." For example, fertilization, which once seemed to be a simple discrete event, is now recognized as an "extended biologic process." This, he implies, is the reason the question of moral worth is difficult to answer.

Although a more complex process creates confusion because it increases the number of candidate points for the boundary of moral worthiness, there is a more fundamental problem. We are given the scientific observations of embryonic development and asked to define the embryo's moral status at various developmental points. Green is asking us to examine the observations of science to find an answer that can have no scientific content. This is particularly difficult because he has not sufficiently developed the concept of moral worthiness. He gives us no general rules of moral worthiness that would make linkage to observable phenomena possible. Emphasis on the difficulty of drawing a precise moral line obscures the lack of a theory that would permit the drawing of any moral line.

A simple test can determine whether a statement has scientific content. If you cannot conceive of (not necessarily perform) an experiment or observation that could prove a statement wrong, the statement has no scientific content. Science, according to Einstein, implies "empirically testable assertions" Let me illustrate this point using a concept discussed by Green, the human soul. As noted by Pope John Paul II (2000) the soul is an entity that "no scientific technique or empirical method can detect directly." If you could dissect the living body, x-ray its entirety, and analyze all its tissues you would never find the soul. Green asks whether an embryo that retains the potential for twinning could have a unitary soul. He also asks whether a soul can vanish. The answer to these questions can have no scientific content, because there is no conceivable experiment or observation that would prove (or disprove) whether an embryo contained a soul or whether a soul could vanish. If you cannot observe the soul, how can you observe that it has vanished? I could declare that embryos destined for twinning have two separate souls. Since there is no conceivable experiment that could prove me wrong, my statement would also have no scientific content. Human souls may exist, but not in the world of science.

Moral worthiness, as presented by Green, also cannot be observed. It comes with no measurable characteristics. Green doesn't even tell us whether moral worthiness is restricted to animate entities. When the Taliban in Afghanistan destroyed ancient Buddhist religious art, there was moral outrage. Does this mean those objects had moral worthiness? Do holy places and holy books have moral worthiness? Moral worthiness, as presented by Green, may exist-but like the soul, not in the world of science. Green's primary problem identifying moral worthiness is not the complexity of biologic processes; the problem is that no matter how closely we examine egg, sperm, and their subsequent unitary life we can never identify moral worthiness, because Green hasn't told us what it looks like.

Moral worthiness is a human construct that can be of no operational value until it is given observable features. Those who believe in the existence of a human soul have endowed that concept with observable characteristics. For example, a body that is certainly dead does not contain a human soul because it is in the defined nature of the soul to depart when the corporeal body dies. Endowing a concept with observable connections does not necessarily make it scientific, but it makes it possible to examine scientific data and impose moral conclusions. Unless Green defines moral worthiness as endowed with observable characteristics, we can study embryology forever and never learn where or if there is moral worthiness. 
2002 